IZA DP No. 936

\title{
Disability, Gender and the Labour Market
}

Melanie K. J ones

Paul L. Latreille

Peter J. Sloane

November 2003 


\title{
Disability, Gender and the Labour Market
}

\author{
Melanie K. Jones \\ University of Wales Swansea \\ Paul L. Latreille \\ University of Wales Swansea \\ Peter J. Sloane \\ University of Wales Swansea \\ and IZA Bonn
}
Discussion Paper No. 936
November 2003

\author{
IZA \\ P.O. Box 7240 \\ D-53072 Bonn \\ Germany \\ Tel.: +49-228-3894-0 \\ Fax: +49-228-3894-210 \\ Email: iza@iza.org
}

This Discussion Paper is issued within the framework of IZA's research area Welfare State and Labor Market. Any opinions expressed here are those of the author(s) and not those of the institute. Research disseminated by IZA may include views on policy, but the institute itself takes no institutional policy positions.

The Institute for the Study of Labor (IZA) in Bonn is a local and virtual international research center and a place of communication between science, politics and business. IZA is an independent, nonprofit limited liability company (Gesellschaft mit beschränkter Haftung) supported by Deutsche Post World Net. The center is associated with the University of Bonn and offers a stimulating research environment through its research networks, research support, and visitors and doctoral programs. IZA engages in (i) original and internationally competitive research in all fields of labor economics, (ii) development of policy concepts, and (iii) dissemination of research results and concepts to the interested public. The current research program deals with (1) mobility and flexibility of labor, (2) internationalization of labor markets, (3) welfare state and labor market, (4) labor markets in transition countries, (5) the future of labor, (6) evaluation of labor market policies and projects and (7) general labor economics.

IZA Discussion Papers often represent preliminary work and are circulated to encourage discussion. Citation of such a paper should account for its provisional character. A revised version may be available on the IZA website (www.iza.org) or directly from the author. 
IZA Discussion Paper No. 936

November 2003

\section{ABSTRACT \\ Disability, Gender and the Labour Market}

Using data from the 2002 LFS, we examine the impact of disability on labour market outcomes by gender. Our results indicate that substantial differences in both the likelihood of employment and levels of earnings exist, despite several years of operation of the Disability Discrimination Act. Significant heterogeneity within the disabled group is identified: those suffering from mental health forms of disability fare particularly badly. Wage decompositions suggest the 'penalty' for disability is greater for women than for men. Using the Baldwin and Johnson (1992) methodology, we find the employment effects associated with wage discrimination against the disabled are very small.

JEL Classification: I1, J2, J3

Keywords: disability, gender, employment, wage discrimination, decomposition analysis

Corresponding author:

Peter J. Sloane

Department of Economics

University of Wales at Swansea

Singleton park

Swansea, SA2 8PP

United Kingdom

Tel.: +441792295168

Fax: +44 1792295872

Email: p.j.sloane@swansea.ac.uk 


\section{INTRODUCTION}

The economic analysis of disabled workers with respect to the labour market has been surprisingly neglected in the UK, especially given the numerical size of this group ${ }^{1}$. Using the 2001 Labour Force Survey (LFS) Smith and Twomey (2002) note that nearly one in five people of working age had a current long term disability in the UK; this amounts to some 3.7 million men and 3.4 million women. As the European Foundation (2003) notes, although cultural factors may operate both across and within countries to influence the incidence of reported disability, only Finland has a higher percentage of the working age population reporting chronic illness or disability than the $\mathrm{UK}^{2}$. The contrast in labour market outcomes for disabled and non-disabled persons is stark: the employment rate for the disabled is just $48 \%$, compared to a rate of $81 \%$ for the non-disabled, while for those disabled people in employment, average earnings are substantially lower than for their non-disabled counterparts.

The above figures are especially striking when considered in the context of legislative and other reforms over the last few years aimed at securing improvements in the labour market position of disabled individuals. The major legal change in this regard was the passing of the Disability Discrimination Act (DDA) in 1995, which was designed to protect the disabled against discrimination and to facilitate and enhance their access to employment by imposing obligations on employers (with 15 or more employees) to make reasonable adjustment to their premises and/or employment arrangements ${ }^{3}$. In addition, a Disability Rights Commission provides advice

\footnotetext{
${ }^{1}$ This contrasts sharply with the US where there has been a substantial increase in publication on such issues following the passing of the Americans with Disabilities Act (ADA) in 1990.

${ }^{2}$ Within the UK the average rate was $18.8 \%$ in 2000 , but this varied between $15.8 \%$ in the South East and $23.9 \%$ in the North East. The differential between regional rates is relatively higher among older persons.

${ }^{3}$ The 1997 Treaty of Amsterdam extended the coverage of Community Law to cover, inter alia, disabilities, and an EU directive of November 2000 prohibits any direct or indirect discrimination based on disability with respect to
} 
and information, supports disabled persons in securing their rights under the DDA, and campaigns on behalf of this group. The Government has also improved incentives to work via the tax and benefit system and more particularly through the Disabled Person's Tax Credit, while the New Deal for Disabled People (NDPP) introduced in July 2001 further attempts to help those out of employment to get back into work. This last policy measure is a voluntary programme whereby disabled people have access to a network of Jobs Brokers whose role is essentially to provide advice about the local labour market and to support individuals in finding and retaining work.

A key issue for policymakers is to determine the extent to which such reforms have achieved their objectives. However, estimation of the impact of legislation and other policy measures in this area is hazardous for a number of reasons. In this regard work in the US is more advanced, and a number of studies has attempted to estimate the employment effects of the Americans with Disabilities Act (ADA). Thus, De Leire (2000) found that on average over the post ADA period, employment of men with disabilities was $7.2 \%$ lower than before the Act was passed. Similar results were obtained by Acemoglu and Angrist (2001), who point out that although the number of disability transfer payments went up, this cannot on its own explain the decline in employment. Consistent with ADA being the explanation, the impact was greater in larger firms (smaller firms being exempt) and in States with more ADA-related discrimination charges. The implication of these results is that the legislation reduced the demand for disabled workers by raising the costs of employing such workers by more than the increase in demand brought about by any reduction in discrimination. However, these results have been questioned on the grounds

employment and occupation. One implication is that the UK will have to extend the coverage of the DDA to cover all employers, including those employing fourteen or fewer workers. 
that the work disability measure used may not accurately reflect coverage under the ADA. Legislation may, by removing the stigma of disability, encourage more individuals to report a disability. Further, some who previously reported a disability prior to the legislation may not do so subsequent to its introduction if improvements to the workplace mean they are no longer limited in their work ${ }^{4}$. As Kruse and Schur (2003) conclude, the analysis of the employment effects of disability legislation is confounded by changes in the composition of those reporting disabilities, the role of disability income and the relative effects of business cycles on workers with and without disabilities.

In the UK, no comparable studies exist that attempt to examine the impact of the DDA. Indeed, to our knowledge there are very few extant economic studies of the labour market outcomes of the disabled. Blackaby et al. (1999) is a comprehensive report prepared for the then Department for Education and Employment (DfEE) using data from the 1991 Census, 1992-4 Quarterly LFS data and the General Household Survey (GHS). Irrespective of data source, the findings indicate that the unemployment probabilities of the disabled/those with long-term health problems are higher than for the non-disabled/those without long-term health problems, while their earnings are lower. Differences in characteristics (productivity) account for a maximum of around half of the differences, the employment differential being perceived as the more substantial (confirming the figures above).

\footnotetext{
${ }^{4}$ Kreider (1999) also points out that we should be cautious in particular about responses from those out of employment, as certain incentives may cause systematic over-reporting of the extent to which a health condition limits work capacity, since health-related work limitations are a socially acceptable reason for not working. Such over-reporting is particularly prevalent among non-working women, high school drop-outs, non-whites and former blue-collar workers. Such biases will lead to over-estimates of the effects of limitations on non-work activity and under-estimates of the effect of income on such activity.
} 
The only study published in an economics journal to date, is that by Kidd et al. (2000) which uses data from the 1996 LFS, but restricts the analysis to males only. These authors again find that human capital/productivity characteristics differences between the disabled and non-disabled explain around $50 \%$ of the wage and participation rate differentials between the two groups. They therefore conclude that, notwithstanding difficulties in interpretation, the size of the residual or unexplained element of the difference (in wages) suggests that it "may, in part, be addressed by the implementation of the 1995 Disability Act" (2000: 979).

The present paper in large part adopts the approach in Kidd et al. using more recent data from the LFS. Importantly however, we do not attempt a formal evaluation of the impact of the DDA using the results of Kidd et al. as a base or benchmark against which to gauge progress. This is in part due to the fact that similar problems apply to those experienced by US researchers examining the ADA. However, these difficulties are compounded in the UK context by a change in the order of the disability questions in the LFS. More specifically, until the Winter of 1997 individuals were asked:

1) if they had health problems which would affect any kind of paid work they might do; and

2) if the health problem would be expected to last more than a year.

From Spring 1997 the order in which these questions were asked was reversed (and an additional question was asked about the amount of paid work the disabled can do). As Cousins, Jenkins and Laux (1998) note, this simple change identified 24\% fewer respondents in the UK reporting a long-term disability which affected the kind of work they might do, and of those it did identify a greater proportion were economically inactive. This makes any attempt to estimate the 
employment effects of the DDA using the LFS hazardous ${ }^{5}$, although we do attempt to offer some insights into its likely impact. In the light of the above difficulties of interpretation concerning pre- and post-legislative changes, both generally and more specifically using the LFS, the present paper focuses instead on gender differences in disability effects in the labour market. Since the relative position of women in the labour market in general is inferior to that of men, at least in terms of earnings, it is clearly of interest to ascertain whether disabled women are similarly disadvantaged relative to disabled men $^{6}$. However, long-term illness affects manual workers disproportionately and men are heavily concentrated in these jobs relative to women, so this is an empirical issue. Further, comparing men and women overcomes many of the difficulties outlined above. The disability rates for men and women of working age are very similar and there is no evidence of differential reporting bias according to gender. Given that the results in Kidd et al. (2000) were restricted to males only, we believe extending the analysis to consider both sexes constitutes an important and original contribution to the UK literature.

In addition, while most studies of discrimination focus on between-group differences in economic outcomes, we also identify within-group differences. Disability varies both in type and intensity, leading to the possibility of omitted variable bias when differences in functional capabilities are excluded. The problem is that it is generally not possible to incorporate these into the analysis of between group differences, since the non-disabled, by definition, do not possess

\footnotetext{
${ }^{5}$ Seasonal differences in the LFS mean that it is not appropriate to limit the analysis to a single quarter. The LFS recorded 16\% more disabled in Winter 1997 than in Spring 1997. Hence the ONS suggests data for Summer, Autumn and Winter are more reliable and imply a decline of only $10 \%$ in the number of disabled compared to the results from the earlier question format.

${ }^{6}$ Haveman et al. (2000) find that disabled men fare somewhat better than disabled women when comparing the size of family income. Stapleton and Burkhauser (2003) using the US Current Population Survey found that mean household income of working-age men without disabilities increased by $12.6 \%$ between 1989 , a peak year in the 1980s business cycle, and 2000, a peak year in the 1990s business cycle, compared to a fall of $2.9 \%$ over the same period for men with disabilities. The corresponding figures for women increased by $12.6 \%$ and $5.6 \%$ respectively.
} 
such disabilities. However, we can compare the case of disabled men and women, including functional limitations in both equations (see Salkever and Domino, 2000) ${ }^{7}$. To anticipate our results somewhat, it is clear that significant differences do exist between types of disability. This is most notable for individuals with mental health problems, whose labour market position appears especially adversely affected. This has potentially important implications for the design of policy, which has hitherto largely focused on physical impairment and adaptation.

The remainder of the paper is structured as follows. In Section 2 we set out the empirical methodology employed, followed in Section 3 by a brief description of the data. Results appear in Section 4, together with a discussion of the implications deriving from these, while conclusions follow in Section 5.

\section{METHODOLOGY}

The standard labour economics model assumes that individuals select that combination of consumption and hours of work which maximises their utility, subject to budget and time constraints. Health may be incorporated into the standard model, either through the budget constraint (via a lower wage offer), the time constraint (via more absences lowering time available for work) or through the utility function itself if poor health reduces utility (see Ettner, 2000).

We follow the traditional labour force participation model in assuming that an individual decides upon whether or not to enter the labour market on the basis of a comparison between the

\footnotetext{
${ }^{7}$ However, their results were rather mixed. Their employment probit results suggest that persons with severe disabilities are more likely to be employed, rather than less, although their wage regressions suggest that those with severe disabilities do earn less.
} 


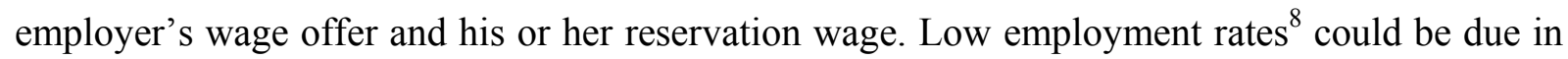
part to high reservation wages associated with certain types of disability as a consequence of disability income transfers and the extra demands on time and energy required to participate in the labour force. Low employment rates might also be due to low market wage rates offered to the disabled as a consequence of lower levels of productivity and/or employer discrimination (Kruse and Schur, 2003).

There are two types of individual: the disabled, represented by $D$ and the non-disabled by $N$. For both of these types the wage offer equation is given by:

$$
W_{i j}^{O}=\beta_{j} X_{i j}+v_{i j} \quad(j=D, N)
$$

where $W_{i j}^{O}$ denotes the logarithm of the (offer) wage, $X_{i j}$ is a vector of productivity related characteristics for individual $\mathrm{i}$ of type $\mathrm{j}$ and $\beta_{j}$ the associated rates of return, making the normal assumptions of the human capital model. The reservation wage is given by:

$$
W_{i j}^{R}=\alpha_{j} Z_{i j}+\varepsilon_{i j} \quad(j=D, N)
$$

where the vector $Z$ incorporates the conventional human capital variables, with the addition of factors influencing the value of time (such as the number of dependent children). We do not directly observe the reservation wage, which is a latent variable, but rather the indicator variable $I$, where $I=1$ if $W_{i j}^{O}>W_{i j}^{R}$ and 0 otherwise. Thus, the probability that an individual works is:

$$
P_{r}\left[W_{i j}^{O}-W_{i j}^{r}>0\right]=P_{r}\left\lfloor\beta_{j} X_{i j}-\alpha_{j} Z_{i j}>\varepsilon_{i j}-v_{i j}\right\rfloor
$$

\footnotetext{
${ }^{8}$ It should be noted that our definition of participation in the empirical section is based on the observation of a positive wage for a particular individual, and therefore strictly speaking relates to employment. This clearly understates the true extent of participation to the extent that it treats the unemployed as non-participants and excludes those in employment with missing wage data (see below).
} 
Assuming that $v_{i j}$ and $\varepsilon_{i j}$ are normally distributed the labour force participation (employment) equation may be estimated by a probit specification.

In estimating the wage equation (1), it is important to correct for sample selection, given that the disabled in particular are unlikely to be a random sub-set of the population as a whole. Indeed, if wage discrimination against disabled workers is substantial and leads to those subject to significant discrimination exiting from the labour force, the estimate of true wage discrimination would be below its true level. Thus, we utilise a Heckman two-stage procedure in which the probit estimates are used to derive the inverse Mills ratio, which is used as an additional regressor in the wage equation.

In estimating the size of the discriminatory wage differential which may exist between disabled and non-disabled employees we follow earlier studies by Lambrinos (1991) and Baldwin and Johnson (1994), based on a technique developed by Reimers (1983). The difference in wage offers between non-disabled $(N)$ and disabled $(D)$ employees can be decomposed as:

$$
\begin{aligned}
& \bar{W}_{N}-\bar{W}_{D}-\left(c_{N} \bar{\lambda}_{N}-c_{D} \bar{\lambda}_{D}\right)=\left(\bar{X}_{N}-\bar{X}_{D}\right) \\
& \left\lfloor\Omega \hat{\beta}_{N}+(1-\Omega) \hat{\beta}_{D}\right\rfloor+\left[\bar{X}_{N}(1-\Omega)-\bar{X}_{D} \Omega\right]\left(\hat{\beta}_{N}-\hat{\beta}_{D}\right)
\end{aligned}
$$

The left-hand side of equation (4) then represents the difference in mean wage offers between non-disabled and disabled employees. The first term on the right-hand side represents that part of the difference in wage offers which is attributable to differences in productivity, while the second term represents that part of the wage difference which is unexplained. The latter is conventionally interpreted as discrimination, but here we are dependent on the types and degrees of disability captured in our measures of these to control for unobserved productivity differences. 
$\Omega$ is a vector representing the relationship between the observed wage structure and the nondiscriminatory norm. It takes values ranging from zero to one depending on which group is the frame of reference given the typical index number problem (see Oaxaca and Ransom, 1994). We provide results using the non-disabled as the base (0), the disabled (1), taking the mean of these two results (0.5), taking ratios given by the shares of the non-disabled and disabled in the working population and finally the figure obtained from a pooled regression $(*)$.

It has been argued that health and employment may be endogenous. Thus in the case of mental health disability, employment may have a positive effect by increasing opportunities for social networking and role satisfaction, but also a negative effect if it increases occupational stress. In the case of physical health, positive effects may arise from the ability of higher income from work to be invested in health improvements, but negative effects from occupational hazards or stress from work overload. In such cases health may be correlated, either positively or negatively with the error term in the participation equations. Such evidence has been found by Ettner (2000) using 1993 US data. Two-thirds of her sample reported either positive or negative effects (more cases being positive than negative). However, using a two-step instrumental variable approach she finds that the effects of health on labour market outcomes are not particularly sensitive to reverse causality. For this reason, and because of the difficulty of finding appropriate instruments in our data set, no attempt is made here to deal with potential problems of endogeneity.

\section{DATA}

We utilise individuals in waves 1 or 5 from each of the four quarters of the 2002 LFS, so as to exclude repeated observations on the same individual (by design individuals remain in the survey for five consecutive quarters). Thus there is no longitudinal element in our sample. The disabled 
are defined as individuals who have a long-term illness (twelve months or more) which limits the type or amount of work they can do, with all other individuals classified as non-disabled. As noted earlier, labour market activity equals one if the individual is an employee with a positive wage, and otherwise is zero 9 .

As Baldwin and Johnson note, in theory all variables in the wage equation should also be included in the employment equation, but clearly some of these variables will not be observed for those not in employment. This could adversely influence the correction for selectivity bias in our equation. Identification is obtained by including a spline variable for the number of children in the household in the employment equation if the respondent is the head of household or their spouse (zero otherwise). In addition to this, we also incorporate a dummy indicating the presence of a labour market income earner in the household in the participation equation. Finally, we use experience and its square in the wage equation, but linear and quadratic terms in age in the employment equation. Qualifications dummies and regional dummies, together with ethnic origin, type of household tenure and number of health problems appear in both employment and wage equations. The latter also includes occupational and industry dummies, the number of days off sick in the reference week, a small establishment dummy, a public sector dummy, a part-time dummy and tenure variables. The hourly pay variable is based on usual weekly pay divided by usual hours, with a dummy variable included also for the amount of usual overtime. In addition to separate estimation by reported disability status, all these equations are estimated separately for men and women, thereby allowing for the possibility that some of the independent variables may have gender specific effects.

\footnotetext{
${ }^{9}$ Individuals who are self-employed, on a government training scheme or who have missing information with regard to their hourly wage or other key variables are excluded from the estimation sample.
} 
In addition, we estimate employment and wage equations for the disabled only augmented by five health type dummies derived from the 17 main health problems identified in the LFS. It was necessary to merge some of these for estimation purposes because of problems of small cell sizes. It should be noted that only just under a quarter of those reporting a health problem claim sickness or disability benefit ${ }^{10}$, but this figure is higher for men $(26 \%)$ than for women $(21 \%)^{11}$. There is also substantial variation in the percentage of those with different types of health problem claiming sickness/disability benefits, ranging from $3.2 \%$ in the case of skin conditions/allergies to $62.1 \%$ in the case of mental illness/phobia. Similar variability occurs in relation to ILO unemployment and inactivity by reported health problem (cf. disability). The former ranges from $1.3 \%$ in the case of 'other' progressive illness to $8.7 \%$ in the case of learning difficulties and the latter from $20.1 \%$ in the case of skin conditions/allergies to $80.1 \%$ in the case of mental illness/phobia. Therefore there is a very wide variation in the extent to which various types of health problem hamper job prospects, with mental illness having the most severe effects. This last statistic confirms the particular difficulties faced by persons with mental illness identified in previous research (see Meager et al., 1998; Bunt et al., 2001).

\section{RESULTS}

The summary mean statistics for the estimation sample in Table 1 show that the disabled men's (employment) participation rate in 2002 was just $39.1 \%$ of that of non-disabled men, with the corresponding figure for women at $44.1 \%$. Disabled men earned $83.1 \%$ of the non-disabled men's level, with the corresponding figure for women at $88.4 \%$. Thus the disadvantage of disabled men relative to non-disabled men is greater than that of disabled women relative to non-

\footnotetext{
${ }^{10}$ These data are based on the estimation sample augmented by those in employment with missing wage information (whose exclusion would otherwise inflate the reported figures).

${ }^{11}$ The corresponding figures for disabled persons are $44 \%, 49 \%$ and $39 \%$ for all, males and females respectively.
} 
disabled women (but even so, both groups of men earn more than even non-disabled women on average). Comparing these figures to those for males reported in Kidd et al. (2000), who used the 1996 LFS (and subject to the caveat given above concerning comparisons over time using this dataset), it would seem that the earnings differential in favour of non-disabled men may have widened (the premium at that time being 14\%). The difference in employment participation rates also appears to have widened, with these rates falling for both non-disabled and disabled men. There is no prima facie evidence therefore, at least on the basis of these data, that the relative position of the disabled has improved over the six years since the introduction of the DDA (but note the caveats in Section 2).

Turning to the other variables in Table 1, a few important differences among the sub-groups are especially worthy of note. In large part these conform to expectations. Thus, for both men and women, disabled persons are on average, less well qualified than their non-disabled counterparts, with the disparity being most acute for the higher qualifications such as degrees. Disabled persons are also typically older (reflecting the fact that many disabilities exhibit age-related onset), and entirely unsurprisingly, suffer from a larger number of health problems than nondisabled individuals. For this reason this group is also more likely to own their own home; they are also however, more likely to be in public housing. Both male and female disabled groups also, on average, are less likely to be in a household where another individual has a source of earned income (for a discussion of which, see below), suggesting that they cannot rely on this as a means to ameliorate their own disadvantage in the labour market. 
For those who are in employment, there are also substantial differences both between the disabled and non-disabled, and also between males and females. These differences include not only the proportions working in particular occupational groups, the public sector and small firms. Men typically work more overtime hours than women, and the non-disabled more than the disabled; this is inversely correlated with the proportions working part-time, as would be expected. Finally, it is especially interesting to note that disabled males and females have longer average tenure than their corresponding non-disabled comparator group.

\subsection{Employment participation}

The employment participation probit estimates are presented in Tables 2 and 3 for men and women respectively. As can be seen, in all cases, Likelihood Ratio tests unambiguously reject the null hypothesis that the coefficients in each regression are jointly insignificant.

Turning to the coefficient estimates, most findings are in accordance with expectations. Thus the results show that both men and women with educational qualifications are significantly more likely to be in employment than those without any qualifications; a finding that applies both for the disabled as well as the non-disabled. However, the marginal effect of each qualification is stronger for the disabled, indicating the particular importance of obtaining qualifications among this group. ${ }^{12}$ There are, in addition, strong age effects, with positive and negative signs on the linear and quadratic terms respectively observed in all cases, conforming to the usual pattern. Married men, whether disabled or not are more likely to be employed than single men, while the reverse applies to women, reflecting conventional household roles. In a similar vein, the presence

\footnotetext{
${ }^{12}$ In terms of the highest qualification the marginal effect is 0.29 for the disabled male and 0.08 for the non-disabled male. A full set of marginal effects are available from the authors on request.
} 
of children generally has a negative effect on participation, although this effect is not significant for disabled men. The presence of an earned source of income by another household member has a positive effect on employment participation, as does possession of a mortgage, while habitation of social housing has the opposite effect. Outright home ownership reduces the likelihood of employment for non-disabled men, but increases it for disabled men. The income variable is especially noteworthy. In particular it should be noted that this is not the conventional measure of unearned income for an individual, which would be expected to reduce labour supply (as found in Kidd et al. 2000). Given the sign of its parameter estimate in Tables 2 and 3, it seems likely that our measure is instead capturing the polarisation of households as being either dual income or no income types (see for example Dickens et al. 2000, Table 4).

For the disabled, having a number of health problems reduces the likelihood of employment. There are also significant regional effects, with lower employment participation rates in regions with slacker labour markets compared to the omitted region (the South-East and London). In contrast to non-disabled men, disabled men have a significantly lower participation rate in East Anglia, but a significantly higher participation rate in the South West. In the case of women, regional differences between the non-disabled and disabled are more marked. In the North-West and Scotland participation is significantly lower for the disabled, but significantly higher for the non-disabled. In other regions there are significant differences for either group, but not the other. On the whole, therefore, particular personal and other characteristics appear to have similar qualitative effects on the probability of employment for both the non-disabled and disabled, although there are some notable exceptions. However, while qualitatively similar, $\chi^{2}$ tests of 
parameter equality among the different comparator sub-groups unambiguously reject the null of homogeneity in each case $\mathrm{e}^{13}$.

\subsection{Earnings}

In general, it seems to be the case also that earnings are determined in a qualitatively similar fashion for disabled and non-disabled persons (Tables 4 and 5), although $\mathrm{F}$ tests of parameter equality are rejected in all cases, and more comprehensively so when comparing men and women than disabled and non-disabled.

In terms of specific coefficient estimates, these are once again largely in accordance with the usual predictions. Thus, wages are higher for those with qualifications relative to those without qualifications in each of the sub-group regressions, with the coefficients generally increasing in magnitude as one progresses up the qualifications hierarchy. Other human capital variables such as (maximum potential) experience and tenure with the current employer are always significant at better than the 1 per cent level, and in both cases there is evidence of the conventional decreasing returns. So far as occupation is concerned, the occupational group dummies are generally significantly negative and of plausible relative magnitudes given the omitted category of managers and senior officials; the only notable exception is females in professional occupations, whose earnings are higher than the base group.

Turning to other variables in these regressions, in conformity with a number of previous studies (see for example Blackaby et al. 1998), wages are higher for married men than for single men,

\footnotetext{
${ }^{13}$ For example, testing the pooling restriction for disabled and non-disabled males results in a $\chi^{2}$ test statistic of 1802.91, while for females the corresponding figure is 1685.27 ; with 28 degrees of freedom, both are clearly significant.
} 
irrespective of whether they are disabled, while the reverse is true for women (albeit this effect is only statistically significant for the non-disabled). Being employed in a small firm (fewer than 20 employees) is associated with lower earnings for all of our sub-groups, while for all except disabled females, the number of health problems and wages are negatively and significantly related. For the housing status variables, these are largely in accordance with priors: being in social housing is negatively related to earnings for all groups, while the reverse is true for those in possession of a mortgage; no relationship is evident for those who own their home outright.

As might be expected a priori given the omitted category (London and the South East), all regional dummies exhibit negative coefficient signs in each of the four sub-group regressions. These are significant with just one exception, namely disabled males in East Anglia. The industry dummies have a fairly consistent effect across the groups, with higher earnings in banking and finance, energy and water, and manufacturing. For males, being employed in agriculture and fishing or distribution and hotels has a significant negative effect for the nondisabled only. Similarly, for females, being employed in distribution and hotels, construction and public administration only affects the wage of the non-disabled group. Interestingly, being employed in the public sector confers a wage advantage for women only. Finally, the selectivity correction term (lambda) is only significant (with positive sign) for disabled women.

\subsection{Earnings and employment participation and type of health problem}

In Tables 6 and 7 we repeat the preceding analysis, but focus on the disabled groups only, incorporating information for each individual concerning their main type of health problem ${ }^{14}$.

\footnotetext{
${ }^{14}$ It seems plausible that this will be the health problem giving rise to the disability, and for this reason we use the two terms interchangeably in this section.
} 
Those with each of the broad types of included health problem/disability are significantly more likely to be in employment than the omitted category of mental health, while individuals with multiple health problems are significantly less likely to be in employment. ${ }^{15}$ The earnings equations also show that those with all types of disability apart from the "other" category earn significantly more than those with mental health problems, with the exception of women with sight/hearing problems. This is in contrast with the earlier work of Kidd et al., where mental health was associated with a lower employment probability only. Using the 2002 data suggests therefore, that of the various disability types, mental health therefore is more problematical both for gaining entry into the labour market and in obtaining earnings comparable to those of other workers. This is an important finding, confirming as it does the findings of inter alia, Bunt et al. (2001) and Meager et al. (1998) concerning the especially acute nature of the labour market disadvantage suffered by those with problems of this type.

The reasons for the acuity of the problem faced by those with mental health problems are difficult to determine but two factors seem likely to be important. The first is that employers may for various reasons, be more reluctant to hire those with mental health problems than with other forms of disability, and consequently when this group do find work, they do so at a lower wage. This reluctance (to hire) is of course a form of discrimination ${ }^{16}$, and precisely the phenomenon that the DDA was designed to address. However, it should be noted that the discrimination may in many cases reflect not prejudice, but rather a lack of knowledge concerning, and misconceptions of, the nature of mental health problems and the consequences of and limitations

\footnotetext{
${ }^{15}$ The marginal effect of the included health dummies being at least 0.12 for males and 0.17 for females.

16 The differences in labour market outcomes between mental health and all other health problems can be decomposed into the effects of characteristics and coefficients. The proportion explained by differences in characteristics is only $19 \%$ for the participation probit but $75 \%$ for the wage gap (using Cotton, 1988 style weights); for employment therefore, coefficient differences represent much the greater part of the phenomenon.
} 
imposed thereby (Brook $2003^{17}$ ). The second is that employers may have a tendency to interpret disability in terms of "physically obvious, or particularly severe, impairments" (Aston et al. 2003: 5), and hence to focus on the physical adaptations to premises required under the DDA, rather than adjustments to working arrangements ${ }^{18}$. This implies that employers may therefore, inadvertently, not be as accommodating to the needs of those with mental health problems. There is also evidence to suggest that they are less likely to make adaptations for new hires (Goldstone with Meager 2002) ${ }^{19}$; the high inactivity rates of those with mental health problems may therefore make this especially problematic for this group when they attempt to (re) join the labour market.

\subsection{Gender and disability decompositions}

A key feature of our analysis is to decompose the differences between the disabled and nondisabled and between genders. Thus we have two types of wage decomposition ${ }^{20}$. The first compares the disabled with the non-disabled separately for men and women, and of necessity excludes types of disability (Table 8). For men, endowments/characteristics are a larger component in explaining the raw differential, which is of the same magnitude for each gender, than are differences in coefficients, while the reverse is the case for women. Whichever basis of comparison is used, the 'unexplained' percentage is always greater for women than for men. This

\footnotetext{
${ }_{17}^{17}$ Article published in the Guardian G2 supplement, 3 June 2003.

18 Examples of working arrangement alterations include re-allocation of duties, changes to working hours, accommodating absence during working hours for treatment, etc.

19 Survey evidence also suggests that employers who have sick/disabled employees do not fully recognise adjustments made to work arrangements unless prompted, or at least to recognise them as being specifically related to disability (Goldstone with Meager 2002).

${ }^{20}$ Decompositions of the employment probits indicate a low 'explained' component (20\% for males, compared to around 50\% in both Blackaby et al. 1999 and Kidd et al. 2000), and for this reason details are not documented here (results are available from the corresponding author on request, together with detailed wage decompositions). To the extent that the 'unexplained' component is interpreted as reflecting discrimination, this suggests that in terms of employment at least, the situation for disabled persons may not have improved since the passing of the DDA.
} 
contrasts with the findings of Blackaby et al. (1999), but is consistent with discrimination being more substantial for disabled women than for disabled men, assuming the same impact from omitted types of disability variables.

Table 9 considers gender wage decompositions to consider whether the disadvantage of disabled women relative to disabled men is greater or less than the disadvantage of non-disabled women to non-disabled men. Again the raw differential is of comparable size in the two cases. While the part of the raw differential explained by endowments and coefficients in the non-disabled comparison is roughly equal, in the disabled comparison the difference in coefficients dominates the difference in endowments. Similarly to Table 8, whatever the basis for comparison used, the percentage 'unexplained' is always greater in the disabled comparison, which is again consistent with the discrimination story. When the type of health problem is controlled for in the gender decomposition (the lower panel of Table 9), the unexplained wage gap increases, indicating there is a gender difference in the impact of types of disability on earnings.

The last aspect of our analysis is to examine the employment implications of the wage discrimination for both men and women. This is undertaken using the Baldwin and Johnson (1992) methodology, deployed in Kidd et al. (2002). The results of this procedure are set out in Table 10. The top part of the table sets out the predicted employment participation probabilities for the disabled and non-disabled in the presence and absence of discrimination, with the nondiscriminatory wage structure being a weighted average of the disabled and non-disabled returns for the gender group under consideration, with the weights being the proportions of each group in the relevant populations (male and female). Predictably, male employment participation rates 
are higher than for females, and for the non-disabled compared to the disabled. As can be seen, the employment effects of changing to the alternative wage structure are in all cases small, particularly for the non-disabled. The group with the largest employment effect is perhaps not surprisingly disabled men, although even here it is scarcely overwhelming. As Kidd et al. (2000: 977-978) indicate, "This is important from a policy viewpoint - it suggests that wage discrimination per se may be important but the implied employment effect associated with the discriminatory wage reduction is very small". In elasticity terms however, our results for men suggest a significantly higher responsiveness to wages for men than found in the previous work of both Kidd et al. for the UK and Baldwin and Johnson in terms of ethnicity for the US. This would appear to indicate that although discrimination in wages may have a small impact overall, disabled men have become more sensitive to wage variations since the passing of the DDA.

\section{CONCLUSIONS}

In this paper, while recognising the difficulties in identifying the impact of disability on labour market outcomes, we compare the effect of disability by gender. The evidence suggests that substantial differences in both likelihood of employment and levels of earnings remain, even after several years of operation of the Disability Discrimination Act. Significant heterogeneity within the disabled group is also identified, with the type of health problem having an important influence on employment and earnings. As with ethnicity, it becomes important to differentiate between the sub-groups to identify those who face the greatest labour market disadvantage. The evidence suggests that those suffering from mental health forms of disability fare particularly badly, and indicates that future efforts may need to be directed towards assisting this particular group. Although our data do not allow us to investigate the reasons for the particularly extreme 
degree of disadvantage faced by this group, it would be surprising if at least part of this did not result from some form of discrimination (and most notably for those (re) joining the labour market). As such, part of the answer may reside in improving employers' access to information concerning the various types of mental illness and their implications for work. It may also be helpful to emphasise the 'reasonable adjustments' that can be made for workers with this type of disability; the popular conception of such adjustments perhaps being more with physical environment.

Our wage decompositions suggest the 'penalty' for disability is greater for women than for men, consistent with the presence of discrimination, although we must note that it is possible that our controls for productivity differences may be imperfect. Finally, we find little evidence using the Baldwin and Johnson (1992) methodology that the employment effects associated with discrimination in wages against the disabled are substantial. However, there is a suggestion that the male disabled may be becoming more sensitive to earnings than in the period prior to the implementation of the DDA. 
Table 1. Basic statistics

\begin{tabular}{|c|c|c|c|c|}
\hline & \multicolumn{2}{|c|}{ Male } & \multicolumn{2}{|c|}{ Female } \\
\hline Variable & Disabled & Non-disabled & Disabled & Non-disabled \\
\hline Hourly pay (£) & 9.307 & 11.207 & 7.494 & 8.465 \\
\hline Proportion in employment & 0.309 & 0.790 & 0.304 & 0.690 \\
\hline Qual 1 & 0.065 & 0.172 & 0.059 & 0.141 \\
\hline Qual 2 & 0.075 & 0.131 & 0.098 & 0.139 \\
\hline Qual 3 & 0.282 & 0.310 & 0.155 & 0.201 \\
\hline Qual 4 & 0.102 & 0.152 & 0.168 & 0.231 \\
\hline Qual 5 & 0.156 & 0.124 & 0.159 & 0.138 \\
\hline Age & 46.837 & 38.129 & 43.745 & 36.969 \\
\hline Age squared & 2372.635 & 1634.930 & 2049.125 & 1510.239 \\
\hline Married & 0.564 & 0.543 & 0.556 & 0.561 \\
\hline Region 1 & 0.084 & 0.053 & 0.069 & 0.053 \\
\hline Region 2 & 0.100 & 0.095 & 0.096 & 0.095 \\
\hline Region 3 & 0.072 & 0.076 & 0.073 & 0.075 \\
\hline Region 4 & 0.029 & 0.034 & 0.033 & 0.033 \\
\hline Region 6 & 0.080 & 0.091 & 0.082 & 0.088 \\
\hline Region 7 & 0.093 & 0.091 & 0.097 & 0.091 \\
\hline Region 8 & 0.116 & 0.100 & 0.122 & 0.102 \\
\hline Region 9 & 0.075 & 0.047 & 0.063 & 0.050 \\
\hline Region 10 & 0.106 & 0.095 & 0.102 & 0.094 \\
\hline White & 0.931 & 0.925 & 0.913 & 0.918 \\
\hline Dependent children & 0.444 & 0.609 & 0.638 & 0.856 \\
\hline Other earner & 0.427 & 0.670 & 0.501 & 0.714 \\
\hline Social housing & 0.339 & 0.113 & 0.350 & 0.155 \\
\hline Home owned & 0.238 & 0.169 & 0.193 & 0.150 \\
\hline Home mortgaged & 0.338 & 0.611 & 0.370 & 0.588 \\
\hline No. of health problems & 2.695 & 0.238 & 2.673 & 0.231 \\
\hline Industry 1 & 0.012 & 0.010 & 0.004 & 0.004 \\
\hline Industry 2 & 0.017 & 0.021 & 0.004 & 0.005 \\
\hline Industry 3 & 0.245 & 0.248 & 0.082 & 0.088 \\
\hline Industry 4 & 0.079 & 0.084 & 0.008 & 0.015 \\
\hline Industry 5 & 0.184 & 0.167 & 0.241 & 0.221 \\
\hline Industry 6 & 0.107 & 0.099 & 0.037 & 0.038 \\
\hline Industry 7 & 0.124 & 0.154 & 0.122 & 0.150 \\
\hline Industry 8 & 0.184 & 0.173 & 0.443 & 0.426 \\
\hline Occupation 2 & 0.096 & 0.137 & 0.077 & 0.109 \\
\hline Occupation 3 & 0.121 & 0.142 & 0.124 & 0.143 \\
\hline Occupation 4 & 0.071 & 0.054 & 0.218 & 0.237 \\
\hline Occupation 5 & 0.171 & 0.158 & 0.024 & 0.016 \\
\hline Occupation 6 & 0.032 & 0.021 & 0.141 & 0.128 \\
\hline Occupation 7 & 0.044 & 0.044 & 0.138 & 0.124 \\
\hline Occupation 8 & 0.156 & 0.127 & 0.032 & 0.028 \\
\hline Occupation 9 & 0.172 & 0.124 & 0.171 & 0.122 \\
\hline
\end{tabular}




\begin{tabular}{|l|c|c|c|c|} 
Experience & 26.471 & 21.496 & 24.807 & 20.634 \\
Experience squared & 866.337 & 623.744 & 757.532 & 571.938 \\
Overtime & 3.842 & 4.291 & 2.269 & 2.468 \\
Tenure & 9.235 & 8.379 & 6.786 & 6.616 \\
Tenure squared & 177.289 & 151.856 & 100.885 & 94.299 \\
Public sector & 0.207 & 0.197 & 0.368 & 0.362 \\
Small firm & 0.265 & 0.235 & 0.318 & 0.294 \\
Part time & 0.121 & 0.075 & 0.498 & 0.426 \\
Days illness & 0.239 & 0.054 & 0.218 & 0.074 \\
\hline
\end{tabular}

Notes: In all cases figures relate to the estimation samples used. 
Table 2. Male labour force participation probit estimates

\begin{tabular}{|c|c|c|c|c|}
\hline & \multicolumn{4}{|c|}{ Male } \\
\hline & \multicolumn{2}{|c|}{ Disabled } & \multicolumn{2}{|c|}{ Non-disabled } \\
\hline & Coefficient & t-stat & Coefficient & t-stat \\
\hline Constant & -3.215 & $-16.14 * * *$ & -4.926 & $-55.61 * * *$ \\
\hline Qual 1 & 0.784 & $11.06 * * *$ & 0.383 & $11.12 * * *$ \\
\hline Qual 2 & 0.855 & $12.75 * * *$ & 0.447 & $12.42 * * *$ \\
\hline Qual 3 & 0.559 & $11.92 * * *$ & 0.336 & $11.60 * * *$ \\
\hline Qual 4 & 0.520 & $8.56 * * *$ & 0.325 & $9.83 * * *$ \\
\hline Qual 5 & 0.525 & $9.77 * * *$ & 0.323 & $9.45 * * *$ \\
\hline Age & 0.125 & $13.89 * * *$ & 0.254 & $56.67 * * *$ \\
\hline Age squared & -0.002 & $-15.38 * * *$ & -0.003 & $-55.26 * * *$ \\
\hline Married & 0.270 & $6.02 * * *$ & 0.217 & $8.46 * * *$ \\
\hline Region 1 & -0.446 & $-6.20 * * *$ & -0.248 & $-6.11 * * *$ \\
\hline Region 2 & -0.049 & -0.79 & -0.048 & -1.46 \\
\hline Region 3 & -0.036 & -0.52 & 0.006 & 0.15 \\
\hline Region 4 & -0.264 & $-2.69 * * *$ & -0.074 & -1.45 \\
\hline Region 6 & 0.139 & $2.13 * *$ & 0.046 & 1.33 \\
\hline Region 7 & 0.033 & 0.52 & 0.015 & 0.43 \\
\hline Region 8 & -0.374 & $-6.11 * * *$ & -0.186 & $-5.86 * * *$ \\
\hline Region 9 & -0.406 & $-5.43 * * *$ & -0.158 & $-3.67 * * *$ \\
\hline Region 10 & -0.240 & $-3.70 * * *$ & -0.093 & $-2.81 * * *$ \\
\hline White & 0.469 & $6.51 * * *$ & 0.624 & $20.07 * * *$ \\
\hline Dependent children & -0.009 & -0.44 & -0.051 & $-4.25 * * *$ \\
\hline Other earner & 0.387 & $10.41 * * *$ & 0.396 & $19.82 * * *$ \\
\hline Social housing & -0.310 & $-4.74 * * *$ & -0.287 & $-8.47 * * *$ \\
\hline Home owned & 0.138 & $2.03 * *$ & -0.106 & $-3.19 * * *$ \\
\hline Home mortgaged & 0.549 & $8.73 * * *$ & 0.393 & $13.76 * * *$ \\
\hline No. of health problems & -0.236 & $-20.46 * * *$ & 0.036 & $2.47 * *$ \\
\hline No obs & \multicolumn{2}{|c|}{8349} & \multicolumn{2}{|c|}{33781} \\
\hline Log likelihood & \multicolumn{2}{|c|}{-3673.015} & \multicolumn{2}{|c|}{-12797.960} \\
\hline$\chi^{2}(p$-value $)$ & \multicolumn{2}{|c|}{$2976.96(0.000)$} & \multicolumn{2}{|c|}{$9114.74(0.000)$} \\
\hline Pseudo- $\mathrm{R}^{2}$ & \multicolumn{2}{|c|}{0.288} & \multicolumn{2}{|c|}{0.263} \\
\hline
\end{tabular}

Notes: Regressions also include dummy variables for the quarter in which the individual was surveyed. ${ }^{* * *},{ }^{* *}$ and ${ }^{*}$ denote significance at the $1 \%, 5 \%$ and $10 \%$ level respectively. The $\chi^{2}$ statistic is a test that all slope coefficients are zero. Pseudo- $\mathrm{R}^{2}$ is McFadden's measure, defined as 1 minus the ratio of the maximised log-likelihood from the regression to that from a regression including the optimal constant only (Maddala, 1983). 
Table 3. Female labour force participation probit estimates

\begin{tabular}{|c|c|c|c|c|}
\hline & \multicolumn{4}{|c|}{ Female } \\
\hline & \multicolumn{2}{|c|}{ Disabled } & \multicolumn{2}{|c|}{ Non-disabled } \\
\hline & Coefficient & t-stat & Coefficient & t-stat \\
\hline Constant & -3.095 & $-14.29 * * *$ & -4.562 & $-53.49 * * *$ \\
\hline Qual 1 & 1.052 & $14.80 * * *$ & 0.660 & $23.25 * * *$ \\
\hline Qual 2 & 0.938 & $16.15 * * *$ & 0.833 & $29.56 * * *$ \\
\hline Qual 3 & 0.720 & $13.97 * * *$ & 0.481 & $19.66 * * *$ \\
\hline Qual 4 & 0.618 & $12.30 * * *$ & 0.502 & $21.17 * * *$ \\
\hline Qual 5 & 0.523 & $10.19 * * *$ & 0.375 & $14.48 * * *$ \\
\hline Age & 0.114 & $10.62 * * *$ & 0.223 & $47.24 * * *$ \\
\hline Age squared & -0.001 & $-10.83 * * *$ & -0.003 & $-42.98 * * *$ \\
\hline Married & -0.137 & $-3.39 * * *$ & -0.261 & $-13.38 * * *$ \\
\hline Region 1 & -0.132 & $-1.88 *$ & -0.017 & -0.52 \\
\hline Region 2 & -0.047 & -0.77 & 0.056 & $2.13 * *$ \\
\hline Region 3 & 0.023 & 0.34 & 0.104 & $3.58 * * *$ \\
\hline Region 4 & -0.071 & -0.77 & -0.004 & -0.10 \\
\hline Region 6 & 0.139 & $2.23 * *$ & 0.157 & $5.68 * * *$ \\
\hline Region 7 & 0.076 & 1.26 & 0.036 & 1.35 \\
\hline Region 8 & -0.257 & $-4.35 * * *$ & 0.064 & $2.47 * *$ \\
\hline Region 9 & -0.229 & $-3.00 * * *$ & -0.004 & -0.11 \\
\hline Region 10 & -0.247 & $-3.92 * * *$ & 0.136 & $5.02 * * *$ \\
\hline White & 0.435 & $6.62 * * *$ & 0.495 & $19.09 * * *$ \\
\hline Dependent children & -0.162 & $-8.09 * * *$ & -0.364 & $-43.92 * * *$ \\
\hline Other earner & 0.402 & $10.44 * * *$ & 0.322 & $17.96 * * *$ \\
\hline Social housing & -0.223 & $-3.50 * * *$ & -0.072 & $-2.60 * * *$ \\
\hline Home owned & 0.025 & 0.37 & -0.008 & -0.27 \\
\hline Home mortgaged & 0.352 & $5.72 * * *$ & 0.427 & $17.80 * * *$ \\
\hline No. of health problems & -0.172 & $-16.49 * * *$ & 0.014 & 1.25 \\
\hline $\begin{array}{l}\text { No obs } \\
\text { Log likelihood } \\
\chi^{2}(\mathrm{p} \text {-value }) \\
\text { Pseudo-R }\end{array}$ & \multicolumn{2}{|c|}{$\begin{array}{c}-3947.932 \\
2172.63(0.000) \\
0.216\end{array}$} & \multicolumn{2}{|c|}{$\begin{array}{c}-20446.192 \\
9144.57(0.000) \\
0.183\end{array}$} \\
\hline
\end{tabular}

Notes: See notes to Table 2. 
Table 4. Male selectivity corrected wage equation.

\begin{tabular}{|c|c|c|c|c|}
\hline & \multicolumn{4}{|c|}{ Male } \\
\hline & \multicolumn{2}{|c|}{ Disabled } & \multicolumn{2}{|c|}{ Non-disabled } \\
\hline & Coefficient & t-stat & Coefficient & t-stat \\
\hline Constant & 1.716 & $14.75 * * *$ & 1.932 & $62.87 * * *$ \\
\hline Region 1 & -0.184 & $-4.65 * * *$ & -0.189 & $-16.33 * * *$ \\
\hline Region 2 & -0.126 & $-4.41 * * *$ & -0.199 & $-22.40 * * *$ \\
\hline Region 3 & -0.166 & $-5.28 * * *$ & -0.172 & $-17.89 * * *$ \\
\hline Region 4 & -0.070 & -1.50 & -0.149 & $-10.94 * * *$ \\
\hline Region 6 & -0.104 & $-3.69 * * *$ & -0.148 & $-16.64 * * *$ \\
\hline Region 7 & -0.132 & $-4.71 * * *$ & -0.150 & $-16.65 * * *$ \\
\hline Region 8 & -0.129 & $-3.99 * * *$ & -0.163 & $-18.22 * * *$ \\
\hline Region 9 & -0.262 & $-6.65 * * *$ & -0.184 & $-15.27 * * *$ \\
\hline Region 10 & -0.157 & $-4.73 * * *$ & -0.161 & $-17.94 * * *$ \\
\hline Occupation 2 & -0.068 & $-1.96 * *$ & -0.062 & $-6.94 * * *$ \\
\hline Occupation 3 & -0.184 & $-5.87 * * *$ & -0.190 & $-21.71 * * *$ \\
\hline Occupation 4 & -0.413 & $-11.13 * * *$ & -0.403 & $-33.64 * * *$ \\
\hline Occupation 5 & -0.388 & $-12.97 * * *$ & -0.413 & $-47.19 * * *$ \\
\hline Occupation 6 & -0.489 & $-9.42 * * *$ & -0.542 & $-29.77 * * *$ \\
\hline Occupation 7 & -0.453 & $-10.01 * * *$ & -0.483 & $-34.95 * * *$ \\
\hline Occupation 8 & -0.478 & $-15.10 * * *$ & -0.511 & $-53.22 * * *$ \\
\hline Occupation 9 & -0.535 & $-17.28 * * *$ & -0.593 & $-59.90 * * *$ \\
\hline Industry 1 & -0.060 & -0.75 & -0.073 & $-2.71 * * *$ \\
\hline Industry 2 & 0.247 & $3.50 * * *$ & 0.217 & $10.64 * * *$ \\
\hline Industry 3 & 0.146 & $3.51 * * *$ & 0.098 & $7.49 * * *$ \\
\hline Industry 4 & 0.205 & $4.44 * * *$ & 0.129 & $8.90 * * *$ \\
\hline Industry 5 & 0.005 & 0.12 & -0.034 & $-2.50 * *$ \\
\hline Industry 6 & 0.148 & $3.35 * * *$ & 0.090 & $6.38 * * *$ \\
\hline Industry 7 & 0.203 & $4.76 * * *$ & 0.201 & $15.02 * * *$ \\
\hline Industry 8 & 0.102 & $2.44 * *$ & 0.017 & 1.23 \\
\hline Days illness & -0.014 & $-1.86 *$ & -0.015 & $-2.75 * * *$ \\
\hline Married & 0.086 & $3.74 * * *$ & 0.067 & $10.95 * * *$ \\
\hline Experience & 0.026 & $8.33 * * *$ & 0.032 & $27.29 * * *$ \\
\hline Exp Squared & 0.000 & $-7.13 * * *$ & -0.001 & $-24.24 * * *$ \\
\hline Qual 1 & 0.463 & $10.01 * * *$ & 0.377 & $30.79 * * *$ \\
\hline Qual 2 & 0.262 & $5.87 * * *$ & 0.202 & $17.14 * * *$ \\
\hline Qual 3 & 0.157 & $4.64 * * *$ & 0.115 & $11.30 * * *$ \\
\hline Qual 4 & 0.179 & $4.85 * * *$ & 0.082 & $7.41 * * *$ \\
\hline Qual 5 & 0.073 & $2.03 * *$ & 0.041 & $3.67 * * *$ \\
\hline Small Firm & -0.115 & $-6.15 * * *$ & -0.131 & $-22.19 * * *$ \\
\hline Part-time & -0.088 & $-3.31 * * *$ & -0.033 & $-3.17 * * *$ \\
\hline White & 0.076 & $1.78 *$ & 0.043 & $3.65 * * *$ \\
\hline Tenure & 0.009 & $3.59 * * *$ & 0.009 & $10.94 * * *$ \\
\hline
\end{tabular}




\begin{tabular}{|l|cc|cc|} 
Ten squared & 0.000 & -0.64 & 0.000 & $-4.32 * * *$ \\
Public Sector & 0.023 & 0.80 & 0.007 & 0.68 \\
Overtime & 0.001 & 0.60 & 0.004 & $11.02 * * *$ \\
No. of health problems & -0.042 & $-3.82 * * *$ & -0.099 & $-8.12 * * *$ \\
Social housing & -0.105 & $-2.73 * * *$ & -0.010 & $-2.51 * *$ \\
Home owned & 0.034 & 0.98 & 0.015 & 1.39 \\
Home mortgaged & 0.100 & $2.78 * * *$ & 0.051 & $5.80 * * *$ \\
Lambda & 0.083 & 1.48 & 0.024 & 1.15 \\
\hline No obs & 2579 & 26692 \\
RSS & 388.924 & 4003.678 \\
F (p-value) & $52.67(0.000)$ & $662.97(0.000)$ \\
$\overline{\mathrm{R}}^{2}$ & 0.496 & \multicolumn{2}{|c|}{0.549} \\
\hline
\end{tabular}

Notes: Regressions also include dummy variables for the quarter in which the individual was surveyed. ${ }^{* * *},{ }^{* *}$ and ${ }^{*}$ denote significance at the $1 \%, 5 \%$ and $10 \%$ level respectively. RSS denotes the residual sum of squares. The F statistic is a test that all slope coefficients are zero. 
Table 5. Female selectivity corrected wage equation.

\begin{tabular}{|c|c|c|c|c|}
\hline & \multicolumn{4}{|c|}{ Female } \\
\hline & \multicolumn{2}{|c|}{ Disabled } & \multicolumn{2}{|c|}{ Non-disabled } \\
\hline & Coefficient & t-stat & Coefficient & t-stat \\
\hline Constant & 1.738 & $15.75 * * *$ & 1.930 & $73.70 * * *$ \\
\hline Region 1 & -0.210 & $-6.06 * * *$ & -0.169 & $-15.98 * * *$ \\
\hline Region 2 & -0.172 & $-6.01 * * *$ & -0.160 & $-19.40 * * *$ \\
\hline Region 3 & -0.116 & $-3.79 * * *$ & -0.152 & $-16.95 * * *$ \\
\hline Region 4 & -0.166 & $-3.99 * * *$ & -0.131 & $-10.22 * * *$ \\
\hline Region 6 & -0.122 & $-4.56 * * *$ & -0.140 & $-17.05 * * *$ \\
\hline Region 7 & -0.146 & $-5.34 * * *$ & -0.137 & $-16.20 * * *$ \\
\hline Region 8 & -0.151 & $-4.88 * * *$ & -0.146 & $-18.15 * * *$ \\
\hline Region 9 & -0.153 & $-3.91 * * *$ & -0.141 & $-12.97 * * *$ \\
\hline Region 10 & -0.210 & $-6.45 * * *$ & -0.139 & $-17.05 * * *$ \\
\hline Occupation 2 & 0.112 & $2.69 * * *$ & 0.054 & $4.99 * * *$ \\
\hline Occupation 3 & -0.056 & -1.55 & -0.131 & $-13.61 * * *$ \\
\hline Occupation 4 & -0.277 & $-8.46 * * *$ & -0.331 & $-36.86 * * *$ \\
\hline Occupation 5 & -0.411 & $-7.33 * * *$ & -0.493 & $-25.71 * * *$ \\
\hline Occupation 6 & -0.449 & $-12.45 * * *$ & -0.490 & $-46.55 * * *$ \\
\hline Occupation 7 & -0.436 & $-11.47 * * *$ & -0.463 & $-42.56 * * *$ \\
\hline Occupation 8 & -0.446 & $-8.08 * * *$ & -0.555 & $-33.85 * * *$ \\
\hline Occupation 9 & -0.495 & $-13.78 * * *$ & -0.551 & $-50.72 * * *$ \\
\hline Industry 1 & -0.057 & -0.47 & 0.005 & 0.14 \\
\hline Industry 2 & 0.365 & $2.84 * * *$ & 0.222 & $7.01 * * *$ \\
\hline Industry 3 & 0.149 & $3.38 * * *$ & 0.132 & $10.10 * * *$ \\
\hline Industry 4 & 0.104 & 1.20 & 0.162 & $7.80 * * *$ \\
\hline Industry 5 & -0.004 & -0.12 & -0.026 & $-2.24 * *$ \\
\hline Industry 6 & 0.094 & $1.89 *$ & 0.172 & $11.49 * * *$ \\
\hline Industry 7 & 0.228 & $5.93 * * *$ & 0.191 & $16.61 * * *$ \\
\hline Industry 8 & 0.050 & 1.47 & 0.029 & $2.72 * * *$ \\
\hline Days illness & -0.017 & $-2.02 * *$ & -0.009 & $-1.95 *$ \\
\hline Married & -0.020 & -1.18 & -0.012 & $-2.24 * *$ \\
\hline Experience & 0.016 & $5.76 * * *$ & 0.021 & $25.63 * * *$ \\
\hline Exp squared & 0.000 & $-5.51 * * *$ & 0.000 & $-24.58 * * *$ \\
\hline Qual 1 & 0.390 & $7.41 * * *$ & 0.351 & $28.93 * * *$ \\
\hline Qual 2 & 0.247 & $5.45 * * *$ & 0.200 & $17.94 * * *$ \\
\hline Qual 3 & 0.177 & $4.53 * * *$ & 0.101 & $10.46 * * *$ \\
\hline Qual 4 & 0.138 & $3.81 * * *$ & 0.058 & $6.26 * * *$ \\
\hline Qual 5 & 0.083 & $2.39 * *$ & 0.047 & $4.78 * * *$ \\
\hline Small firm & -0.059 & $-3.44 * * *$ & -0.071 & $-13.95 * * *$ \\
\hline Part-time & -0.058 & $-3.41 * * *$ & -0.030 & $-5.68 * * *$ \\
\hline White & -0.035 & -0.89 & -0.006 & -0.55 \\
\hline Tenure & 0.015 & $5.02 * * *$ & 0.015 & $15.84 * * *$ \\
\hline
\end{tabular}




\begin{tabular}{|l|cc|cc|} 
Ten squared & 0.000 & $-2.45^{* *}$ & 0.000 & $-5.99 * * *$ \\
Public sector & 0.112 & $4.91 * * *$ & 0.054 & $7.63^{* * *}$ \\
Overtime & 0.005 & $2.51^{* *}$ & 0.004 & $7.71^{* * *}$ \\
No. of health problems & -0.009 & -0.26 & -0.029 & $-2.71^{* * *}$ \\
Social housing & -0.024 & $-2.97 * * *$ & -0.007 & $-1.87^{*}$ \\
Home owned & 0.004 & 0.13 & -0.004 & -0.36 \\
Home mortgaged & 0.080 & $2.51 * *$ & 0.026 & $3.05 * * *$ \\
Lambda & 0.135 & $2.58^{* * *}$ & -0.011 & -0.77 \\
\hline No obs & 2490 & 27907 \\
RSS & 334.748 & 3742.959 \\
F (p-value) & $47.74(0.000)$ & $628.06(0.000)$ \\
$\overline{\mathrm{R}}^{2}$ & 0.479 & \multicolumn{2}{|c|}{0.524} \\
\hline
\end{tabular}

Notes: See notes to Table 4. 
Table 6. Disabled labour force participation probits

\begin{tabular}{|c|c|c|c|c|}
\hline & \multicolumn{2}{|c|}{ Male } & \multicolumn{2}{|c|}{ Female } \\
\hline & Coefficient & t-stat & Coefficient & t-stat \\
\hline Constant & -3.878 & $-18.48 * * *$ & -3.929 & $-17.07 * * *$ \\
\hline Qual 1 & 0.763 & $10.53 * * *$ & 1.076 & $14.68 * * *$ \\
\hline Qual 2 & 0.825 & $12.09 * * *$ & 0.900 & $15.19 * * *$ \\
\hline Qual 3 & 0.497 & $10.42 * * *$ & 0.693 & $13.15 * * *$ \\
\hline Qual 4 & 0.474 & $7.62 * * *$ & 0.605 & $11.78 * * *$ \\
\hline Qual 5 & 0.482 & $8.84 * * *$ & 0.507 & $9.70 * * *$ \\
\hline Age & 0.133 & $14.39 * * *$ & 0.127 & $11.41 * * *$ \\
\hline Age squared & -0.002 & $-16.25 * * *$ & -0.002 & $-11.94 * * *$ \\
\hline Married & 0.218 & $4.80 * * *$ & -0.157 & $-3.82 * * *$ \\
\hline Region 1 & -0.469 & $-6.40 * * *$ & -0.149 & $-2.08 * *$ \\
\hline Region 2 & -0.070 & -1.11 & -0.082 & -1.32 \\
\hline Region 3 & -0.048 & -0.67 & 0.014 & 0.20 \\
\hline Region 4 & -0.275 & $-2.75 * * *$ & -0.083 & -0.89 \\
\hline Region 6 & 0.110 & $1.66^{*}$ & 0.132 & $2.08 * *$ \\
\hline Region 7 & 0.004 & 0.06 & 0.063 & 1.02 \\
\hline Region 8 & -0.371 & $-5.97 * * *$ & -0.268 & $-4.46 * * *$ \\
\hline Region 9 & -0.417 & $-5.46 * * *$ & -0.255 & $-3.27 * * *$ \\
\hline Region 10 & -0.263 & $-3.99 * * *$ & -0.240 & $-3.72 * * *$ \\
\hline White & 0.520 & $7.11 * * *$ & 0.501 & $7.47 * * *$ \\
\hline Dependent children & -0.028 & -1.36 & -0.184 & $-8.98 * * *$ \\
\hline Other earner & 0.394 & $10.44 * * *$ & 0.369 & $9.38 * * *$ \\
\hline Social housing & -0.283 & $-4.26 * * *$ & -0.223 & $-3.41 * * *$ \\
\hline Home owned & 0.161 & $2.32 * *$ & 0.032 & 0.46 \\
\hline Home mortgaged & 0.556 & $8.68 * * *$ & 0.351 & $5.57 * * *$ \\
\hline No. of health problems & -0.233 & $-19.98 * * *$ & -0.169 & $-15.83 * * *$ \\
\hline Health 1 & 0.719 & $11.93 * * *$ & 0.816 & $13.79 * * *$ \\
\hline Health 2 & 0.815 & $8.61 * * *$ & 0.720 & $7.08 * * *$ \\
\hline Health 3 & 0.836 & $13.63 * * *$ & 0.924 & $14.91 * * *$ \\
\hline Health 5 & 0.375 & $5.17 * * *$ & 0.497 & $7.38 * * *$ \\
\hline No obs & & & & \\
\hline Log likelihood & -35 & & -3.7 & \\
\hline$\chi^{2}(p$-value $)$ & 3205.5 & 000) & 2442.7 & $000)$ \\
\hline Pseudo- $\mathrm{R}^{2}$ & & & & \\
\hline
\end{tabular}

Notes: See notes to Table 2. 
Table 7. Disabled selectivity corrected wage equation

\begin{tabular}{|c|c|c|c|c|}
\hline & \multicolumn{2}{|c|}{ Male } & \multicolumn{2}{|c|}{ Female } \\
\hline & Coefficient & t-stat & Coefficient & t-stat \\
\hline Constant & 1.673 & $12.79 * * *$ & 1.620 & $11.95 * * *$ \\
\hline Region 1 & -0.179 & $-4.58 * * *$ & -0.213 & $-6.13 * * *$ \\
\hline Region 2 & -0.123 & $-4.32 * * *$ & -0.176 & $-6.10 * * *$ \\
\hline Region 3 & -0.163 & $-5.21 * * *$ & -0.118 & $-3.84 * * *$ \\
\hline Region 4 & -0.062 & -1.32 & -0.166 & $-3.99 * * *$ \\
\hline Region 6 & -0.106 & $-3.78 * * *$ & -0.126 & $-4.67 * * *$ \\
\hline Region 7 & -0.136 & $-4.84 * * *$ & -0.148 & $-5.39 * * *$ \\
\hline Region 8 & -0.120 & $-3.76 * * *$ & -0.154 & $-4.95 * * *$ \\
\hline Region 9 & -0.256 & $-6.56 * * *$ & -0.155 & $-3.96 * * *$ \\
\hline Region 10 & -0.154 & $-4.67 * * *$ & -0.209 & $-6.47 * * *$ \\
\hline Occupation 2 & -0.067 & $-1.93 *$ & 0.114 & $2.72 * * *$ \\
\hline Occupation 3 & -0.181 & $-5.76 * * *$ & -0.054 & -1.50 \\
\hline Occupation 4 & -0.413 & $-11.11 * * *$ & -0.277 & $-8.43 * * *$ \\
\hline Occupation 5 & -0.386 & $-12.86 * * *$ & -0.414 & $-7.33 * * *$ \\
\hline Occupation 6 & -0.489 & $-9.43 * * *$ & -0.452 & $-12.50 * * *$ \\
\hline Occupation 7 & -0.457 & $-10.11 * * *$ & -0.439 & $-11.51 * * *$ \\
\hline Occupation 8 & -0.479 & $-15.12 * * *$ & -0.449 & $-8.12 * * *$ \\
\hline Occupation 9 & -0.533 & $-17.21 * * *$ & -0.496 & $-13.76 * * *$ \\
\hline Industry 1 & -0.068 & -0.84 & -0.054 & -0.44 \\
\hline Industry 2 & 0.227 & $3.21 * * *$ & 0.359 & $2.78 * * *$ \\
\hline Industry 3 & 0.133 & $3.20 * * *$ & 0.147 & $3.31 * * *$ \\
\hline Industry 4 & 0.194 & $4.19 * * *$ & 0.095 & 1.09 \\
\hline Industry 5 & -0.005 & -0.12 & -0.007 & -0.18 \\
\hline Industry 6 & 0.136 & $3.09 * * *$ & 0.093 & $1.87 *$ \\
\hline Industry 7 & 0.194 & $4.52 * * *$ & 0.227 & $5.91 * * *$ \\
\hline Industry 8 & 0.094 & $2.25 * *$ & 0.050 & 1.46 \\
\hline Days illness & -0.014 & $-1.76^{*}$ & -0.017 & $-1.97 * *$ \\
\hline Married & 0.077 & $3.61 * * *$ & -0.024 & -1.36 \\
\hline Experience & 0.025 & $8.03 * * *$ & 0.016 & $5.82 * * *$ \\
\hline Exp squared & 0.000 & $-6.83 * * *$ & 0.000 & $-5.65 * * *$ \\
\hline Qual 1 & 0.447 & $10.03 * * *$ & 0.392 & $7.45 * * *$ \\
\hline Qual 2 & 0.248 & $5.82 * * *$ & 0.243 & $5.49 * * *$ \\
\hline Qual 3 & 0.139 & $4.39 * * *$ & 0.174 & $4.55 * * *$ \\
\hline Qual 4 & 0.160 & $4.49 * * *$ & 0.137 & $3.82 * * *$ \\
\hline Qual 5 & 0.058 & $1.70 *$ & 0.081 & $2.36 * *$ \\
\hline Small firm & -0.116 & $-6.20 * * *$ & -0.058 & $-3.35 * * *$ \\
\hline Part-time & -0.079 & $-2.95 * * *$ & -0.056 & $-3.29 * * *$ \\
\hline White & 0.072 & $1.69 *$ & -0.027 & -0.66 \\
\hline Tenure & 0.010 & $3.72 * * *$ & 0.015 & $5.03 * * *$ \\
\hline Ten squared & 0.000 & -0.73 & 0.000 & $-2.43 * *$ \\
\hline
\end{tabular}




\begin{tabular}{|c|c|c|c|c|}
\hline Public sector & 0.018 & 0.62 & 0.108 & $4.73 * * *$ \\
\hline Overtime & 0.001 & 0.45 & 0.004 & $2.46 * *$ \\
\hline No. of health problems & -0.103 & $-2.71 * * *$ & -0.010 & -0.27 \\
\hline Social housing & -0.036 & $-3.46 * * *$ & -0.024 & $-2.99 * * *$ \\
\hline Home owned & 0.028 & 0.82 & 0.006 & 0.18 \\
\hline Home mortgaged & 0.087 & $2.47 * *$ & 0.079 & $2.50 * *$ \\
\hline Lambda & 0.058 & 1.10 & 0.141 & $2.66 * * *$ \\
\hline Health1 & 0.117 & $2.80 * * *$ & 0.138 & $3.07 * * *$ \\
\hline Health2 & 0.146 & $2.80 * * *$ & 0.084 & 1.47 \\
\hline Health3 & 0.121 & $2.74 * * *$ & 0.143 & $3.01 * * *$ \\
\hline Health5 & 0.057 & 1.34 & 0.069 & 1.62 \\
\hline No obs & \multicolumn{2}{|c|}{2573} & \multicolumn{2}{|l|}{. } \\
\hline RSS & \multicolumn{2}{|c|}{386.103} & \multicolumn{2}{|c|}{333.495} \\
\hline $\mathrm{F}$ (p-value) & \multicolumn{2}{|c|}{$49.03(0.000)$} & \multicolumn{2}{|c|}{$43.92(0.000)$} \\
\hline$\overline{\mathrm{R}}^{2}$ & \multicolumn{2}{|c|}{0.497} & \multicolumn{2}{|c|}{0.478} \\
\hline
\end{tabular}

Notes: See notes to Table 4. 
Table 8. Disabled and non-disabled wage decomposition

\begin{tabular}{|c|c|c|c|c|c|c|c|c|c|c|}
\hline & \multicolumn{5}{|c|}{ Male } & \multicolumn{5}{|c|}{ Female } \\
\hline Mean prediction non-disabled & \multicolumn{5}{|c|}{2.238} & \multicolumn{5}{|c|}{1.990} \\
\hline Mean prediction disabled & \multicolumn{5}{|c|}{2.010} & \multicolumn{5}{|c|}{1.760} \\
\hline Raw differential & \multicolumn{5}{|c|}{0.228} & \multicolumn{5}{|c|}{0.230} \\
\hline - due to endowments & \multicolumn{5}{|c|}{0.162} & \multicolumn{5}{|c|}{0.118} \\
\hline - due to coefficients & \multicolumn{5}{|c|}{0.119} & \multicolumn{5}{|c|}{0.152} \\
\hline - due to interaction & \multicolumn{5}{|c|}{-0.053} & \multicolumn{5}{|c|}{-0.040} \\
\hline D: & 0 & 1 & 0.5 & 0.912 & $*$ & 0 & 1 & 0.5 & 0.918 & $*$ \\
\hline Unexplained & \multicolumn{5}{|c|}{\begin{tabular}{|l|l|l|l|l|l|l|l|l|l|l|}
0.066 & 0.119 & 0.092 & 0.114 & 0.104 \\
\end{tabular}} & \multicolumn{5}{|c|}{\begin{tabular}{|l|l|l|l|l|l|l|}
0.113 & 0.152 & 0.132 & 0.149 & 0.145 \\
\end{tabular}} \\
\hline Explained & \multicolumn{5}{|c|}{ 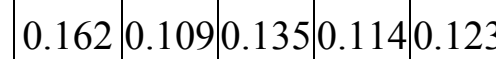 } & \multicolumn{4}{|c|}{\begin{tabular}{|l|l|l|l|l|l|l|l|l|l|l|l|l|l|l|l|l|l|}
0.118 & 0.078 & 0.098 & 0.081 \\
\end{tabular}} & 0.085 \\
\hline$\%$ unexplained & 29 & 52.1 & 40.6 & 50.1 & 45.8 & 48.9 & 66.1 & 57.5 & 64.7 & 63.1 \\
\hline$\%$ explained & 71 & 47.9 & 59.4 & 49.9 & 54.2 & 51.1 & 33.9 & 42.5 & 35.3 & 36.9 \\
\hline Differential due to selection variable & \multicolumn{5}{|c|}{-0.060} & \multicolumn{5}{|c|}{-0.125} \\
\hline
\end{tabular}


Table 9. Gender wage decomposition

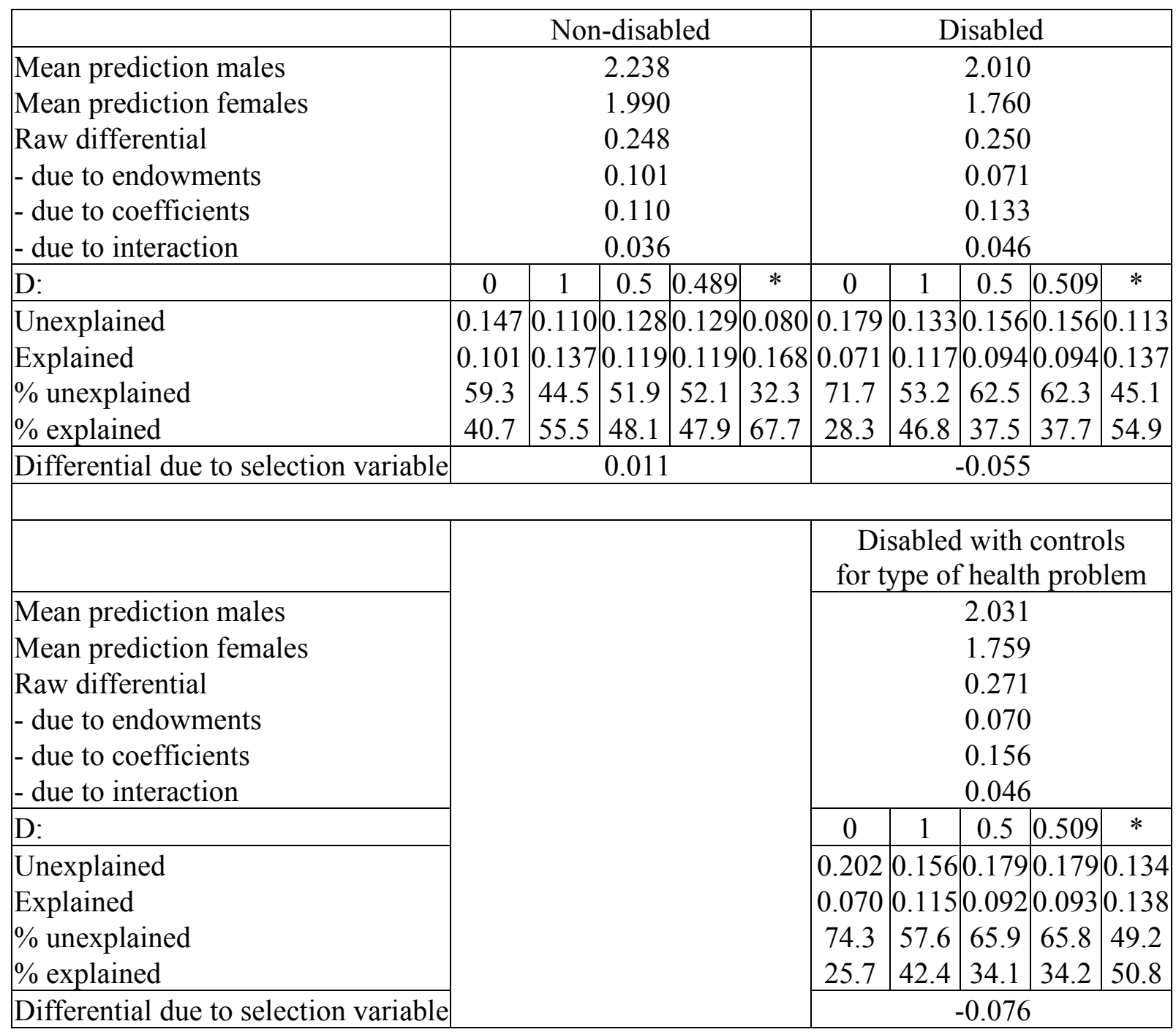


Table 10. Employment effects of wage differences

\begin{tabular}{|l|c|c|}
\hline & Male & Female \\
\hline Employment probability & & \\
- Non-disabled discriminatory & 0.8513 & 0.7202 \\
- Non-disabled non-discriminatory & 0.8509 & 0.7200 \\
- Disabled discriminatory & 0.2343 & 0.2494 \\
- Disabled non-discriminatory & 0.2456 & 0.2498 \\
\hline Employment elasticities & & \\
- Non-disabled & 0.212 & 0.109 \\
- Disabled & 1.514 & 0.149 \\
\hline
\end{tabular}




\section{VARIABLE DEFINITIONS}

\section{Dependent variables}

(Log) hourly wages

Employment

participation

Human capital variables

Experience

Tenure

Qual 1

Qual 2

Qual 3

Qual 4

Qual 5

Qual 6

Industry variables

Industry 1

Industry 2

Industry 3

Industry 4

Industry 5

Industry 6

Industry 7

Industry 8

Industry 9 and 10

Occupation variables

Occupation 1

Occupation 2

Occupation 3

Occupation 4

Occupation 5

Occupation 6

Occupation 7

Occupation 8

Occupation 9

Region variables

Region 1

Region 2

Region 3
Gross weekly earnings divided by usual hours worked per week Dummy variable equal to 1 if individual has a positive hourly wage, 0 else

Years of (potential) labour market experience (age minus school-leaving age)

Years in present job

Dummy variable, equals 1 if highest qualification is university degree or higher degree

Dummy variable, equals 1 if highest qualification is other degree Dummy variable, equals 1 if highest qualification is A level Dummy variable, equals 1 if highest qualification is $\mathrm{O}$ level Dummy variable, equals 1 if highest qualification is other qualification

Dummy variable, equals 1 if no qualifications (base)

Agriculture and fishing

Energy and water

Manufacturing

Construction

Distribution, hotels etc

Transport communication etc

Banking and finance

Public administration

Other (base)

Managers and senior officials (base)

Professional occupations

Associate professional and technical

Administrative and secretarial

Skilled trades

Personal service occupations

Sales and customer service occupations

Process, plant and machine operatives

Elementary occupations

North

Yorkshire and Humberside

East Midlands 
Region 4

Region 5

Region 6

Region 7

Region 8

Region 9

Region 10

\section{Health variables}

Days illness

No of health problems

Health 1

Health 2

Health 3

Health 4

Health 5

Housing status variables

Social housing

Home owned

Home mortgaged

Private rent

Other variables

Age

Married

Dependent children

Other earner

White

Small firm

Public

Part-time

Overtime
East Anglia

South East and London (base)

South West

West Midlands

North West

Wales

Scotland

Number of days off sick in the reference week (0-7)

Number of health problems reported

Dummy variable, equals 1 if main health problem affects limbs Dummy variable, equals 1 if main health problem affects sight/hearing

Dummy variable, equals 1 if main health problem affects skin, breathing and organs

Dummy variable, equals 1 if main health problem is mental health (base)

Dummy variable, equals 1 if main health problem is other

Dummy variable, equals 1 if renting from non-private sector

Dummy variable, equals 1 if home owned outright

Dummy variable, equals 1 if home mortgaged

Dummy variable, equals 1 if renting from private sector (base)

Age (years)

Dummy variable denoting marital status, equals 1 if married

Number of dependent children in household if head of household or spouse ( 0 else)

Dummy variable, equals lif there is another individual in household has a labour market income

Dummy variable denoting ethnic group, equals 1 if white

Dummy variable denoting marital status, equals 1 if less than 20 employees in firm

Dummy variable, equals 1 if individual is employed in the public sector

Dummy variable, equals 1 if employed part time

Amount of usual overtime (hours) 


\section{REFERENCES}

Acemoglu D. and Angrist J.D. (2001) 'Consequence of Employment Protection? The Case of the Americans with Disabilities Act', Journal of Political Economy, Vol. 19, Issue 5, pp 91550

Aston J., Atkinson J., Evans C., Davis S. and O'Regan S. (2001) Employers and the New Deal for Disabled People: Qualitative Research - First Wave, Department for Work and Pensions, Research Report No. 145, London

Baldwin M. and Johnson W.G. (1994) 'Labor Market Discrimination Against Men with Disabilities', Journal of Human Resources, Vol. XXIX (1), pp 1-19

Baldwin M. and Johnson W.G. (2000) 'Labor Market Discrimination Against Men with Disabilities in the Year of the ADA', Southern Economic Journal, Vol. 66, No. 3, pp 548-66

Blackaby D.H., Carlin P.S. and Murphy P.D. (1998) 'What A Difference A Wife Makes: Evidence of Women Investing in Their Husband's Careers', Bulletin of Economic Research, Vol. 50, No.1, pp 1-18

Blackaby D., Clark K., Drinkwater S., Leslie D., Murphy P. and O’Leary N. (1999) Earnings and Employment Opportunities of Disabled People, Department for Education and Employment, Research Report No.133, Nottingham

Bunt K., Shury J., Vivian D. and Allard F. (2001) Recruiting Benefit Claimants: A Survey of Employers in One Pilot Areas, Department for Work and Pensions, Research Report No. 139, London

Cotton, J. (1988) 'On the decomposition of wage differentials', Review of Economics and Statistics, Vol. 70, No. 2, pp 236-243

Cousins C., Jenkins J. and Laux R. (1998) 'Disability Data from the LFS: Comparing 1997-98 with the Past', Labour Market Trends, June, pp 321-340

De Leire T. (2000) 'The Wage and Employment Effects of the Americans with Disabilities Act', Journal of Human Resources, Vol. 35, No. 4, pp 693-715

Dickens R., Gregg P. and Wadsworth J. (2000) 'New Labour and the Labour Market', Oxford Review of Economic Policy, Vol. 16, No. 1, pp 95-113

Ettner, Susan L. (2000) 'The Relationship between Labour Market Outcomes and Physical and Mental Health; Exogenous Human Capital or Endogenous Health Production?' in Salkever D.S. and Sorkin A. (eds.) The Economics of Disability, Research in Human Capital and Development, Vol. 13, JAI Press Inc.: Stamford, Connecticut 
European Foundation for the Improvement of Living and Working Conditions (2003) Illness,Disability and Social Inclusion, Office for Official Publications of the European Communities, Luxembourg

Goldstone C. with Meager N. (2002) Barriers to Employment for Disabled People, Department for Work and Pensions, In-house Report No. 95, London

Haveman R., Holden K., Wolfe B., Smith P. and Wilson K. (2000) 'The Changing Economic Status of Disabled Women, 1982-1991; Trends and their Determinants', in Salkever D.S. and Sorkin A. (eds.), The Economics of Disability, op. cit.

Kidd M.P., Sloane P.J. and Ferko I. (2000) 'Disability and the Labour Market; An Analysis of British Males', Journal of Health Economics, Vol. 19, pp 961-81

Kreider B. (1999) 'Latent Work Disability and Reporting Bias', Journal of Human Resources, Vol. XXXIV, No. 4, pp 734-69

Kruse D. and Schur, L. (2003) 'Employment of People with Disabilities Following the ADA', Industrial Relations, Vol. 42, No. 1, pp 31-64

Lambrinos J. (1991) 'Health; A Source of Bias in Labour Supply Models', Review of Economics and Statistics, Vol. 73, pp 203-212

Maddala G.S. (1983) Limited Dependent and Qualitative Variables in Econometrics, Econometric Society Monographs No. 3, Cambridge: Cambridge University Press

Meager N., Bates P., Dench S., Honey S. and Williams M. (1998) Employment of Disabled People: Assessing the Extent of Participation, Department for Education and Employment Research Brief No. 69, London

Oaxaca R.L. and Ransom M. (1994) 'On Discrimination and the Decomposition of Wage Differentials', Journal of Econometrics, Vol. 61, pp 5-21

Reimers C.W. (1983) 'Labor Market Discrimination Against Hispanic and Black Men', Review of Economics and Statistics, Vol. 65, pp 570-579

Salkever D.S. and Domino Marisa E. (2000) 'Within Group "Structural” Tests of Labor-Market Discrimination; A Study of Persons with Serious Disabilities', in Salkever D.S. and Sorkin A. (eds.), The Economics of Disability, op. cit.

Smith A. and Twomey B. (2002) 'Labour Market Experience of People with Disabilities', Labour Market Trends, August, pp 415-27

Stapleton D. and Burkhauser R.V. (eds.) The Decline in the Employment of People with Disabilities; A Policy Puzzle, WE. Upjohn Institute for Employment Research: Kalamazoo, Michigan 


\section{IZA Discussion Papers}

\begin{tabular}{|c|c|c|c|c|}
\hline No. & Author(s) & Title & Area & Date \\
\hline 922 & $\begin{array}{l}\text { J. Merz } \\
\text { D. Burgert }\end{array}$ & $\begin{array}{l}\text { Working Hour Arrangements and Working Hours } \\
\text { - A Microeconometric Analysis Based on } \\
\text { German Time Use Diary Data }\end{array}$ & 5 & $11 / 03$ \\
\hline 923 & $\begin{array}{l}\text { U. Dulleck } \\
\text { P. Frijters } \\
\text { R. Winter-Ebmer }\end{array}$ & $\begin{array}{l}\text { Reducing Start-Up Costs for New Firms: The } \\
\text { Double Dividend on the Labour Market }\end{array}$ & 5 & $11 / 03$ \\
\hline 924 & $\begin{array}{l}\text { A. P. Damm } \\
\text { M. Rosholm }\end{array}$ & $\begin{array}{l}\text { Employment Effects of Dispersal Policies on } \\
\text { Refugee Immigrants, Part I: Theory }\end{array}$ & 1 & $11 / 03$ \\
\hline 925 & $\begin{array}{l}\text { A. P. Damm } \\
\text { M. Rosholm }\end{array}$ & $\begin{array}{l}\text { Employment Effects of Dispersal Policies on } \\
\text { Refugee Immigrants, Part II: Empirical Evidence }\end{array}$ & 1 & $11 / 03$ \\
\hline 926 & $\begin{array}{l}\text { S. E. Black } \\
\text { P. J. Devereux } \\
\text { K. G. Salvanes }\end{array}$ & $\begin{array}{l}\text { Why the Apple Doesn't Fall Far: Understanding } \\
\text { Intergenerational Transmission of Human } \\
\text { Capital }\end{array}$ & 5 & $11 / 03$ \\
\hline 927 & $\begin{array}{l}\text { L. Goette } \\
\text { D. Huffman } \\
\text { E. Fehr }\end{array}$ & Loss Aversion and Labor Supply & 5 & $11 / 03$ \\
\hline 928 & $\begin{array}{l}\text { H. Selod } \\
\text { Y. Zenou }\end{array}$ & $\begin{array}{l}\text { Does City Structure Affect the Labor-Market } \\
\text { Outcomes of Black Workers? }\end{array}$ & 3 & $11 / 03$ \\
\hline 929 & $\begin{array}{l}\text { Z. Eckstein } \\
\text { G. J. van den Berg }\end{array}$ & Empirical Labor Search: A Survey & 1 & $11 / 03$ \\
\hline 930 & $\begin{array}{l}\text { M. Lindeboom } \\
\text { F. Portrait } \\
\text { G. J. van den Berg }\end{array}$ & $\begin{array}{l}\text { Individual Mortality and Macro Economic } \\
\text { Conditions from Birth to Death }\end{array}$ & 3 & $11 / 03$ \\
\hline 931 & P. Kooreman & $\begin{array}{l}\text { Time, Money, Peers, and Parents: Some Data } \\
\text { and Theories on Teenage Behavior }\end{array}$ & 5 & $11 / 03$ \\
\hline 932 & $\begin{array}{l}\text { H. N. Mocan } \\
\text { E. Tekin }\end{array}$ & $\begin{array}{l}\text { Guns, Drugs and Juvenile Crime: Evidence from } \\
\text { a Panel of Siblings and Twins }\end{array}$ & 3 & $11 / 03$ \\
\hline 933 & $\begin{array}{l}\text { W. Arulampalam } \\
\text { A. L. Booth } \\
\text { M. L. Bryan }\end{array}$ & Training in Europe & 5 & $11 / 03$ \\
\hline 934 & $\begin{array}{l}\text { M. Piva } \\
\text { E. Santarelli } \\
\text { M. Vivarelli }\end{array}$ & $\begin{array}{l}\text { The Skill Bias Effect of Technological and } \\
\text { Organisational Change: Evidence and Policy } \\
\text { Implications }\end{array}$ & 5 & $11 / 03$ \\
\hline 935 & T. J. Dohmen & $\begin{array}{l}\text { Performance, Seniority and Wages: Formal } \\
\text { Salary Systems and Individual Earnings Profiles }\end{array}$ & 1 & $11 / 03$ \\
\hline 936 & $\begin{array}{l}\text { M. K. Jones } \\
\text { P. L. Latreille } \\
\text { P. J. Sloane }\end{array}$ & Disability, Gender and the Labour Market & 3 & $11 / 03$ \\
\hline
\end{tabular}

An updated list of IZA Discussion Papers is available on the center's homepage www.iza.org. 